\title{
Knowledge and Attitudes towards Road Safety Awareness among Secondary School Students in Batu Pahat, Johor
}

\author{
Mustaffa Anjang Ahmad ${ }^{\mathrm{a}}$, Siti Athirah Topika, Kamarudin Ambak ${ }^{\mathrm{a}}$, Munzilah Md Rohania, Nur Sabahiah Abd Sukor ${ }^{\mathrm{b}}$ \\ ${ }^{a}$ Smart Driving Research Center, Faculty of Civil And Environmental Engineering, Universiti Tun Hussein Onn Malaysia, 86400 Parit Raja, Johor, Malaysia \\ ${ }^{b}$ School of Civil Engineering, Engineering Campus, Universiti Sains Malaysia, 14300 Nibong Tebal, Penang, Malaysia
}

*Corresponding author: kamardin@uthm.edu.my

Article history: Received 19 April 2017 Received in revised form: 28 January 2018 Accepted: 11 April 2019 Published online: 31 August 2019

\begin{abstract}
Road safety awareness is a important element subject in which also involved school students. The school students are the most prone group ef that become the victims of the road accidents. This study is carried out to identify the road safety awareness, knowledge, driving attitudes among secondary school students in Parit Raja, Johor. The study was involved a total of 298 school students as respondents. The questionnaires were distributed and the data were processed using descriptive statistics, t-test, correlation and regression analyses. The descriptive analysis shows, more than half of respondents are those aged 16 years old. About $76.5 \%$ of them do not have the driving license. The result also shows that the road safety awareness among the students is at quite high level (mean score $=3.57$ ). Next, t-test and regression analysis shows that every $1 \%$ increase in road safety awareness will affect $35.0 \%$ of increase to driving attitude among students $(\mathrm{p}<0.05, \beta=0.35)$. Besides that, the factor analysis, items in the variable of Road Safety Factor shows that there are three methods of road safety are identified; Environment of Highway, Uses of Highway and Law of Road Safety. Therefore, road safety awareness and driving attitudes are the important factors to ensure the road user concern to road safety. However, some improvements to the existing road facility or road safety deficiencies in Parit Raja need to be undertaken to ensure the road is safer to others.
\end{abstract}

Keywords: Knowledge; attitudes; road safety awareness; secondary school; impacts

\begin{abstract}
Abstrak
Kesedaran keselamatan jalan raya adalah satu perkara yang sangat penting juga turut melibatkan pelajar sekolah. Pelajar-pelajar sekolah merupakan kumpulan yang paling terdedah yang menjadi mangsa kemalangan jalan raya. Kajian ini dijalankan untuk mengenal pasti kesedaran keselamatan jalan raya, pengetahuan dan sikap memandu dalam kalangan pelajar sekolah menengah di Parit Raja, Johor. Kajian ini melibatkan 298 pelajar sekolah menengah sebagai responden. Soal selidik telah diedarkan dan data telah diproses dengan menggunakan statistik deskriptif, ujian-t, korelasi dan regresi analisis. Analisis deskriptif mendapati lebih separuh daripada responden berusia 16 tahun dan analisis menunjukkan $76.5 \%$ daripada mereka tidak mempunyai lesen memandu. Hasil kajian juga menunjukkan bahawa kesedaran keselamatan jalan raya di dalam kalangan pelajar berada pada tahap agak tinggi $($ skor min $=$ 3.57). Seterusnya, ujian-t dan analisis regresi menunjukkan bahawa setiap peningkatan $1 \%$ dalam keselamatan jalan raya akan member kesan kesedaran peningkatan sebanyak $35.0 \%$ kepada sikap memandu (nilai $\mathrm{p}<0.05, \beta=0.35$. Selain itu, analisis faktor melalui item pembolehubah Faktor Keselamatan Jalan Raya menunjukkan bahawa terdapat tiga kaedah keselamatan jalan raya telah dikenal pasti; Persekitaran Jalan Raya, Kegunaan Jalan Raya dan Undang-undang Keselamatan Jalan Raya. Oleh itu, kesedaran keselamatan jalan raya dan sikap pemandu merupakan faktor utama bagi memastikan pengguna jalan raya lebih mementing keselamatan di jalan raya. Walau bagaimanapun, beberapa penambahbaikan kepada fasiliti jalan raya atau aspek kelemahan keselamatan jalan raya yang sedia ada di Parit Raja perlu ada bagi memastikan jalan raya adalah lebih selamat kepada pengguna.
\end{abstract}

Kata kunci: Pengetahuan; sikap; kesedaran keselamatan jalan raya; sekolah menengah; impak

(C) 2019 Penerbit UTM Press. All rights reserved

\subsection{INTRODUCTION}

Road traffic accidents and injuries is a public health problem worldwide. Based on the road accidents worldwide, it has claimed that the lives of nearly 1.2 million people were killed and 50 people are injured each year (WHO, 2010). Meanwhile, accidents involving secondary school students increased by $60 \%$ of road deaths involving motorcyclists aged between 16 and 25 years who did not have a valid driving license (Kazmi \& Jubair, 2014). Deaths due to injuries on the roads have contributed to the loss of various parties in terms of lives, human resources, property, and money (Shahid et al. 2015). Road accident worldwide was the 9th in the chart as the cause of death and is estimated to be the 5th in the chart by 2020 (WHO, 2015).Globally, the cause of death due to injury in the streets preceded by 
adolescents aged from 15-19 years, followed by children aged from 5 to 14 years (WHO, 2010). According to The Institution of Civil Engineers (1996), the human factor is the biggest contributor to road accidents, followed by environmental factors and vehicle factors. Roads play an important role in the rapid developing city in order for traffic on the roads running smoothly. Malaysia is currently undergoing a process of rapid development which involves various economic activities, movement of goods and people as well as the networking of road transportation and its directly becoming more complex. Simultaneously, the industrial areas are located in residential areas while the business district located in urban centers. This leads to an increase in the number of vehicles to transport individuals who indirectly cause traffic congestion, traffic hazards and increase urban pollution (WHO, 2010). This problem also indirectly suffered by students who were among a group of road users. According to Mohd Solhi and Yusof (2014), stated that teenagers are the most victims of road accidents. The area has many intersections to vehicles in and out, roads with high capacity vehicles, and areas with sharp corners are dangerous areas and high risk for accidents.

Roads in Batu Pahat especially in Parit Raja often used by locals including the students from schools and colleges. The safety of students will be endangered, especially for schools that are built too close to the road which exposed to the risk of road accidents (Rothman et al., 2016). According to statistics , a total of 369 number of deaths from road accidents have occurred on the route Batu Pahat - Ayer Hitam throughout 2010 and 2011 (Mohd Solhi \& Yusof, 2014).There is a great lost in potential healthy years of life of productivity among the youthful group. There is also minimal information on safety practices particularly among adolescent who are also a major road user in the country. Therefore, this study was aimed to identify the road safety awareness among secondary school students by using the survey forms. Also, to identify the effectiveness of existing road safety factor at study area, Parit Raja.

\section{Driving Attitudes and Road Safety Factors}

The attitude of road users is a key aspect in the issue of road accidents. In addition, Rosli et al., (2015) defines the different attitude from the perspective of the field of Social Sciences of a person's character (Person's bodily position) and the person's thought (Person's posture of mind). Attitude is a combination of motivations, emotions, perceptions and cognitive processes that occur regularly (Ajzen, 2005). Attitude is also not something that is available there since birth but must be learned, formed and developed through experience.

Numerous efforts were made to change the attitudes of road users. For example through public information campaigns and driver education, law enforcement, increased fines and summons forth. However, all these efforts are less effective and far from achieving the real goal. Therefore, it is timely study of the attitudes and relationship with road safety scientifically conducted to locate and identify the problems that arise and to propose an effective action plan to address and control the rate of road accidents. Research on the attitudes of road users is important to examine why and how it was formed and attitudes can change and affect driving accidents happen eventually (Karim, 2010).

Road accidents can be reduced by using the method 3E; Engineering, Education and Enforcement (Talib et al., 2003). Measures that can be done in the engineering approach is to provide a more comfortable environment for users such as widening and straightening roads which are narrow and winding, provide clear signage, providing sidewalks and bike paths, orderly crossing and bright street lights. Educational approach is aimed to sensitize road users to be prudent and disciplined while on the road such as road safety campaigns, especially in schools to provide early exposure on the importance of road safety. Next, the enforcement approach also aims to change the behaviour and attitude of road users who always underestimate road safety.

\section{Road Accidents}

Table 1 shown the number of deaths caused by transport accidents by detailed group in 2012 in Malaysia (MOH, 2014). The statistics of deaths are involving pedestrians ( 26 cases), motorcyclists ( 242 cases), and the truck or van rider ( 48 cases). The number of cases involving motorcycle riders showed the highest rate, followed by a truck or van riders and pedestrians. This shows that the majority of motorists ridden by teenagers, who are still in school, are more prone to accidents on the roads either only involving injury or death (Sullman et al., 2012).

Table 1 Mortality Rate (per 100,000 populations) by Advanced Group In 2012, Malaysia

\begin{tabular}{lcc}
\hline Transport accidents by Advanced Group & No. of deaths & $\begin{array}{c}\text { The death rate } \\
\text { (per 100,000 population) }\end{array}$ \\
\hline Pedestrian & 26 & 0.09 \\
Bikers & 242 & 0.84 \\
Three wheel drive vehicle riders & 19 & 0.07 \\
Car Riders & 1 & 0.00 \\
Truck or van Riders & 48 & 0.17 \\
Heavy transport vehicles Riders & 7 & 0.02 \\
Bus riders & 12 & 0.04 \\
\hline
\end{tabular}

Refer to Table 2, accident statistics are divided into three areas according to section consisting of sections 13-18 (Jalan Sri Gading), section 19-24 (Jalan Parit Raja) and section 25-39 (Jalan Ayer Hitam). Based on the number of such statistics, a section 19-24 of the road in Parit Raja has recorded the highest number of accidents in 2010 (285 cases) and 2011 (302 cases). The number of death, light injury and 
damage cases for those three sections were increasing from 2010 to 2011 . Thus, routes in Parit Raja should be aware of the high user capability based on the being of industrial areas as well as educational institutions because of the risk of accidents to occur are very high.

Table 2 Statistics on Accidents at Jalan Ayer Hitam - Sri Gading

\begin{tabular}{ccccccc}
\hline Year & No. Section & Death & Severe & Light & Damage only & Total \\
\hline \multirow{2}{*}{2010} & $13-18$ & 2 & 1 & 7 & 99 & 109 \\
& $19-24$ & 6 & 0 & 28 & 251 & 285 \\
& $25-39$ & 8 & 1 & 21 & 249 & 279 \\
\hline \multirow{2}{*}{$\mathbf{2 0 1 1}$} & $13-18$ & 2 & TOTAL & 1 & $\mathbf{6 7 3}$ \\
& $19-24$ & 6 & 2 & 21 & 273 & 138 \\
& $25-39$ & 8 & 2 & 37 & 238 & 285 \\
\hline \multicolumn{5}{c}{ TOTAL } \\
\hline \multicolumn{5}{c}{ Source: Yusof \& Mohd Solhi (2014) } \\
\end{tabular}

Therefore, this study was conducted to determine the level of road safety awareness and driving attitudes among secondary school students. Adolescent Road Behaviour Questionnaire (ARBQ) was produced by Elliot and Baugh (2004) to study the behavior of road among teenagers.

\subsection{METHODOLOGY}

For this study, ARBQ has been used as a reference in generating the questions in the survey form. Some question the criteria that lead to teen safety on the roads identified can be attributed to the research topic, so as to generate questions based on the study. There are three factors studied through ARBQ of unsafe crossing behavior, the dangers of playing on the road and the protective planned behaviour. ARBQ has proved to be useful and effective for studying the behavior of the level of safety in relation to the likelihood of an accident (Karim, 2010).

The questionnaire was designed for this study based on ARBQ in various versions that have been processed and also adapted from Mohamad and Ahmad (1997). In addition, the questionnaire is divided into five parts, the first part is the information of respondents, the second part is driving attitude on highway, the third part is the level of awareness of safe driving, the fourth part is the road safety factors, and the fifth is an open question prioritizing proposals and comments from respondents regarding the survey. The measurement scale using a 5-Likert scale which 1 is Very Disagree to 5 is Very Agree.

Consequently, the study area was selected secondary schools in Parit Raja. The data were collected within two months period started in February until March 2016. The questionnaire forms were distributed in several schools such as SMK Seri Gading, SMK Datuk Menteri and SMK Tun Ismail. Respondents were among secondary school students from Level 4 to Level 6 which were randomly chosen in terms of race, gender and race.

Based on the total population of Johor state in 2013, people aged between 16 to 19 which are majority in Form 4 , Form 5 and Form 6 Upper Primary is about 116,000 persons (DOSM, 2014). However, based on studies Ahmed et al., (2013) a number of 300 respondents were chosen as a representative sample of the general characteristics of them and the survey achieved a response rate of 57\% (of 533 respondents were approached). Therefore, this study chose the sample size $(n=300)$.

In this study, the quantitative method (statistical analysis) was used to quantify the variables in the survey form. The details analysis includes descriptive statistics, reliability (coefficient alpha), regression analysis, correlation analysis, T-test analysis and factor analysis. The analyses of data were then using Statistical Package for Science Social (SPSS) version 22.0.

\subsection{RESULTS AND DISCUSSION}

Socio-Demographic of School Students

Table 3 provides the descriptive analysis on profile of respondents. About $41.9 \%$ of respondents are those aged 16 years old and more than half $(76.5 \%)$ of the respondents do not possess a driving license. This is critical, meanings that they are riding a vehicle without a basic knowledge of road regulations. Alarmingly, over $56.0 \%$ of them were rode a motorcycle to the school. Ministry of Health of Malaysia (2014) reported that the death rate per 100,000 populations was 0.84 and among the bikers. The rate was the highest among the others (pedestrian, car riders, bus and van riders, and etc.). 
Table 3 Socio-demographic of respondents

\begin{tabular}{|c|c|c|c|c|c|}
\hline Description & $\mathbf{N}$ & $\%$ & Description & $\mathbf{N}$ & $\%$ \\
\hline Gender & & & Guardian's income & & \\
\hline Male & 123 & 41.3 & RM500 and below & 25 & 8.4 \\
\hline \multirow[t]{2}{*}{ Female } & 175 & 58.7 & RM501-RM1500 & 164 & 55.0 \\
\hline & & & RM1501-RM3000 & 70 & 23.5 \\
\hline Age & & & RM3001 and above & 39 & 13.1 \\
\hline 16 & 125 & 41.9 & & & \\
\hline 17 & 91 & 30.5 & Guardian's job & & \\
\hline 18 & 4 & 1.3 & Government worker & 96 & 32.2 \\
\hline 19 & 77 & 25.8 & Private worker & 53 & 17.8 \\
\hline \multirow[t]{2}{*}{20} & 1 & 0.3 & Labour & 68 & 22.8 \\
\hline & & & Business & 41 & 13.8 \\
\hline Nationality & & & Others & 40 & 13.4 \\
\hline Malay & 284 & 95 & Total & 298 & 100.0 \\
\hline \multirow[t]{2}{*}{ Chinese } & 14 & 5 & Summon experience & & \\
\hline & & & Yes & 22 & 7.4 \\
\hline Transport used & & & No & 276 & 92.6 \\
\hline Car & 55 & 18.5 & & & \\
\hline Motorcycle & 167 & 56.0 & License availability & & \\
\hline Bus & 36 & 12.1 & Yes & 70 & 23.5 \\
\hline Van & 10 & 3.4 & No & 228 & 76.5 \\
\hline Others & 30 & 10.0 & & & \\
\hline \multicolumn{6}{|l|}{$\begin{array}{l}\text { Guardian's } \\
\text { education levels }\end{array}$} \\
\hline \multirow[t]{2}{*}{ SPM } & 185 & 62.1 & & & \\
\hline & 49 & 16.4 & & & \\
\hline \multicolumn{6}{|c|}{ Diploma/Polytech } \\
\hline Degree & 29 & 9.7 & & & \\
\hline Master/PHD & 9 & 3.0 & & & \\
\hline Others & 26 & 8.8 & & & \\
\hline
\end{tabular}

Road Safety Awareness and Driving Attitudes associated with Gender

This section investigates the differences between male and female based on road safety awareness and driving attitudes. T-test was used in order to determine if there any significant differences among study variables with gender of respondents. Result in Table 4 revealed that ttest for road safety awareness is -2.468 ( $\mathrm{p}$-value $<0.05$ ) and it is statistically significant. It shows that there is a difference in significant level of road safety awareness by gender. The girls $($ Mean Score $=3.62)$ have a greater awareness than male students $($ Mean Score $=3.49)$. Next, the result of safe driving attitudes by t-test is 1.598 and p-values less than 0.05 . Since p-value less than 0.05 , that's means the driving attitudes of the driver is significant difference between boys and girls. The girls (Mean Score $=3.45$ ) had a higher safe driving attitude than male students (Mean Score $=3.84$ ).

Table 4 T-test between road safety awareness and driving attitudes by gender

\begin{tabular}{|c|c|c|r|r|}
\hline Variables & \multicolumn{2}{|c|}{ Mean Score } & T-value & p-value* \\
\hline & \multicolumn{1}{|c|}{ Male } & Female & & \\
\hline $\begin{array}{c}\text { Road Safety } \\
\text { Awareness }\end{array}$ & 3.409 & 3.620 & -2.468 & $0.014^{*}$ \\
\hline Driving Attitudes & 3.450 & 3.840 & 1.598 & $0.016^{*}$ \\
\hline
\end{tabular}

Impacts of Road Safety Awareness on Safe Driving Attitudes

Table 5 shows the regression analysis of road safety awareness and safe driving attitudes among secondary school students in Parit Raja. Overall, the F-test is 35.005 and a p-value <0.05 was significant. The results show that when there is an increase in the level of consciousness, it affects safe driving attitude by students of secondary schools in Parit Raja. The result of $\mathrm{R}^{2}$ is 0.106 , it describes that the total variance of the road safety awareness is by 10.6 percent against the students driving attitudes. This relationship of both variables is 
$10.6 \%$ and has a low strength. The t-test for the road safety awareness and safe driving attitudes is $5.916(\mathrm{p}$-value $=0.000)$. P-values for ttest is significant and the beta value $(\beta)$ is 0.350 . When the beta value $(\beta)=0.350$, it can be concluded that when the road safety awareness increased by 1 percent, it will have an impact on the increase of safe driving attitudes among the students as much as 35.0 percent.

Table 5 Regression Analysis

\begin{tabular}{lccc}
\hline Relationship & $\begin{array}{c}\text { Beta } \\
\text { value }(\boldsymbol{\beta})\end{array}$ & p-value & T-test \\
\hline Road Safety Awareness \& Driving & 0.350 & 0.000 & 5.916 \\
Attitudes & & 35.005 & \\
F-Test (p-value) & & $(0.000)$ & \\
& & 0.106 & \\
$\mathrm{R}^{2}$ & & & \\
\hline
\end{tabular}

\section{Factor of Road Safety}

Table 6 shows the results of exploratory factor analysis of 14 items in the section D (Road Safety Factors). The results indicated that the Kaiser-Meyer-Olkin Measure of Sampling Adequancy (KMO) value is 0.74 exceeds 0.60 suggested by Hair et al., (2006). While the Bartlett's Test of Sphericity is 753.412 (great value) and the p-value for this test was 0.000 (p-value <0.05). When the KMO value more than 0.60 and p-value of Bartlett's Test of Sphericity less than 0.05 , it indicates the appropriate data using exploratory factor analysis to determine the existence of factors.

Further investigation may be continued with view values of the charge for each item. After the rotation of the first run, the entire load factor exceeds 0.50 and there are three factors that exist by collecting the items together in each factor. The collection of these items in the three factors cited by outperforms suitability statement. Thus, the first group that gathers seven items was named as the "Environment around the Road" .While the second charge of collecting the three items were named as the "Road Usages". There are four outstanding items in the third factor, were named as the "Legislation by the Authority".

In the factor of environment around of roads, the item that should be emphasized is improving accessibility for motorcycles. Then, for road usage factor, the item that should be given more attention is put on the luxury car drivers who drive with the speed of his own volition than usual brand car driver. The most important item need to be improve from the factor of legislation by the authority is the determination of the speed limit to be determined in each area, have contributed to the driver does not comply.

Table 6 Factor Analysis (Exploratory Factors of Road Safety)

\begin{tabular}{|c|c|c|c|c|c|}
\hline \multirow[t]{2}{*}{ Items } & \multicolumn{3}{|c|}{ Load Value } & \multirow[t]{2}{*}{ Score Mean } & \multirow[t]{2}{*}{ Rank } \\
\hline & 1 & 2 & 3 & & \\
\hline \multicolumn{6}{|l|}{ Environment Around The Road } \\
\hline The condition of the roads around your area are good & 0.57 & & & 3.44 & 2 \\
\hline $\begin{array}{l}\text { The traffic lights around your area are good in } \\
\text { functions }\end{array}$ & 0.67 & & & 4.03 & 6 \\
\hline Pedestrian facilities are well and safe conditions & 0.75 & & & 3.51 & 3 \\
\hline $\begin{array}{l}\text { Warning signs around your neighborhood are in right } \\
\text { way and easy to understand }\end{array}$ & 0.71 & & & 3.97 & 5 \\
\hline The motorcycle routes in your area is good & 0.70 & & & 3.33 & 1 \\
\hline $\begin{array}{l}\text { The use of life jackets / bright clothes is important } \\
\text { when riding a motorcycle at night }\end{array}$ & 0.63 & & & 4.19 & 7 \\
\hline $\begin{array}{l}\text { Street lights around your area suitable for vehicle } \\
\text { drivers }\end{array}$ & 0.64 & & & 3.91 & 4 \\
\hline \multicolumn{6}{|l|}{ Road Usages } \\
\hline $\begin{array}{l}\text { Speeding is acceptable if you're driving a } \\
\text { nice/expensive car }\end{array}$ & & 0.71 & & 2.79 & 1 \\
\hline $\begin{array}{l}\text { Driving slowly than the speed limit is dangerous } \\
\text { because it allows other drivers overtaking in harm } \\
\text { way }\end{array}$ & & 0.60 & & 3.53 & 3 \\
\hline $\begin{array}{l}\text { The need to choose a safe speed limit is up to the } \\
\text { individuals }\end{array}$ & & 0.65 & & 3.03 & 2 \\
\hline \multicolumn{6}{|l|}{ Legislation By The Authority } \\
\hline The speed limit in your area are appropriate & & & 0.87 & 3.79 & 3 \\
\hline $\begin{array}{l}\text { The speed limit In Parit Raja area is limited cause the } \\
\text { drivers do not obey }\end{array}$ & & & 0.51 & 3.34 & 1 \\
\hline Strict enforcement of speed limits is required & & & 0.74 & 3.67 & 2 \\
\hline $\begin{array}{l}\text { When the enforcement has set a traffic regulation } \\
\text { code, it must be obeyed even you do not agree }\end{array}$ & & & 0.85 & 3.90 & 4 \\
\hline $\begin{array}{l}\text { Kaiser-Meyer-Olkin Measure of Sampling Adequacy. } \\
\text { (KMO) }\end{array}$ & \multicolumn{5}{|c|}{0.74} \\
\hline Bartlett's Test of Sphericity & \multicolumn{5}{|c|}{ 753.412(0.000) } \\
\hline
\end{tabular}


Correlation of Road Safety Awareness, Driving Attitudes and Road Safety Factors

Table 7 shows the correlation analysis of the variables of road safety awareness, driving attitudes and road safety factors. The result shows that between variables of road safety awareness and driving attitudes have a positively significant correlation by value of 0.219 . Next, the value of 0.067 shows that the association between variables driving attitudes and road safety factors is positive but not significant as the value $(\mathrm{p}=0.254>0.05)$. Meanwhile, the variables of road safety awareness and road safety factors have negatively significant relationship by value of -0.166 . Overall, the result showed that the road safety awareness will give effect to the driving attitudes on the road of students and vice versa. The road safety factors also depend on the driving attitudes of the students while driving on the road.

Table 7 Correlation Analysis

\begin{tabular}{ccc}
\hline Correlations & Pearson Correlation & p-value \\
\hline Road Safety Awareness ---> Driving Attitudes & 0.219 & $0.000^{* *}$ \\
Road Safety Awareness ---> Road Safety Factors & -1.66 & $0.005^{* *}$ \\
Driving Attitudes ---> Road Safety Factors & 0.067 & 0.254 \\
\hline Note: ** Correlation is significant at the 0.01 level (2-tailed)
\end{tabular}

\subsection{CONCLUSION}

It is vital to concern on road safety awareness among school students, whereby there is lack enforcement activity has been carried out. Even though, the respondents have good enough knowledge and attitude regarding the importance of safety on the roads. However, when it's translated into their daily practices might be the other way around. It can be concludes that school students are easily influenced by attitude and their surroundings either from the family or close friends and other people in the intention to do something. Strictly on law enforcement and the knowledge of driving attitudes on the roads are needed in order to mitigate the problem regarding the road safety awareness among the school students.

\section{Acknowledgement}

The authors would like to express our appreciation to the Universiti Tun Hussein Onn Malaysia (UTHM) and Smart Driving Research Center (SDRC), Faculty of Civil and Environmental Engineering for giving support and comfort whilst the study was conducted.

\section{References}

Ahmed, M.B., Ambak, K., Raqib, A. \& Sukor, N.S. (2013). Helmet Usage among Adolescents in Rural Road from the Extended Theory of Planned Behaviour. Journal of Applied Sciences, 13, 161-166.

Ajzen, I. (2005). Attitudes, Personality and Behaviour. $2^{\text {nd }}$ ed. Open University Press. England.

Department of Statistic Malaysia (2014). Population estimated based on the Population and Housing Census of Malaysia 2010. Accessed on October $22,2014$. https://newss.statistics.gov.my/newss-portalx/ep/epFreeDownloadContentSearch.seam?cid=18289.

Elliot, M.A. \& Baugh, C.J. (2004). Developing a Self-Report Method For Investigating Adolescent Road User Behaviour, Transportation Research Part F, 373-393.

Hair, J. F., Black, W. C., Babin, B. J., Anderson, R. E. (2006). Multivariate Data Analysis. 7th edition. Prentice Hall, Englewood Cliffs.

Karim, S. (2010). Kajian Kemalangan Jalan Raya di KM1.7 hingga KM2.1 di Jalan Negeri Shah Alam - Batu Arang Daerah Petaling Selangor Darul Ehsan. Universiti Teknologi Malaysia. Tesis Ijazah Sarjana Muda.

Kazmi, J. H. \& Zubair, S. (2014). Estimation of Vehicle Damage Cost Involved in Road Traffic Accidents in Karachi, Pakistan: A Geospatial Perspective, 77, 70-78.

Mohamad, F. \& Ahmad, O. (1997). Risiko Kemalangan Jalan Raya di Kalangan Kanak-kanak Sekolah Rendah di Kuala Terengganu. Jabatan Kesihatan Masyarakat, Fakulti Perubatan, Universiti Kebangsaan Malaysia. Kuala Lumpur

Mohd Solhi, N.S. \& Yusof, Y. (2014). Kesan Pembangunan Jalan Raya Terhadap Pembelajaran Pelajar dari Aspek Keselamatan. Universiti Tun Hussein Onn Malaysia. Malaysia.

Ministry of Health of Malaysia. (2014). Kadar Kematian (Bilangan dan Kadar) Mengikut Negeri dan Jantina, Malaysia. Achieved at January 15, 2015, from http://www.moh.gov.my/images/gallery/publications/md/hi/hi.pdf

Rothman, L., Howard, A., Buliung, R., Macarthur, C. and Macpherson, A., 2016. Dangerous Student Car Drop-Off Behaviors And Child Pedestrian-Motor Vehicle Collisions: An Observational Study. Traffic Injury Prevention, 17(5), 454-459.

Rosli, N., Ambak, K., Daniel, B.D. \& J. Prasetijo. (2015). Penerimaan Sistem Penguatkuasaan Automatik (AES) dalam Kalangan Pemandu Menggunakan Model Penerimaan Teknologi. Jurnal Teknologi, 75(1), 1-6.

Shahid, S., Minhans, A., Puan, O.C., Hasan, S.A. and Ismail, T., 2015. Spatial and Temporal Pattern Of Road Accidents And Casualties In Peninsular Malaysia. Jurnal Teknologi, 76(14), 57-65.

Sullman, M.J.M, Thomas, A. \& Stephens, A.N. (2012). The Road User Behaviour of School Students in Belgium. Cranfield University. United Kingdom.

The Institution Of Civil Engineers. (1996). Transport: 50 Years of Road Safety. Achieved on November 27, 2014. http://www.ice.org.uk/ICE_Web_Portal/media/westmidlands/2013-03-26-Road-Safety-Seminar.pdf

Talib, J.R., Mustafa,M.F., Kemin, S. \& Kasiran, R. (2003). Kemalangan Jalan Raya : Analisis Data Membabitkan Pengguna Motorsikal. Universiti Teknologi Malaysia.

World Health Organization (2010). Global Status Report on Road Safety. Achieved on November 11, 2014. http://www.who.int/bulletin/volumes/88/3/10-120313.pdf.

World Health Organization, 2015. Global Status Report On Road Safety 2015. World Health Organization. 